\title{
Leibniz's Observations on Hydrology: An Unpublished Letter on the Great Lombardy Flood of 1705
}

\section{LLOYD STRICKLAND}

Department of History, Politics, and Philosophy, Manchester Metropolitan University, Manchester, M15 6LL, UK

$\underline{\text { L.Strickland@mmu.ac.uk }}$

\section{MICHAEL CHURCH}

Department of Geography, The University of British Columbia, Vancouver, British Columbia, Canada, V6T 1 Z2.

\section{Summary}

Although the historical reputation of Gottfried Wilhelm Leibniz (1646-1716) largely rests on his philosophical and mathematical work, it is widely known that he made important contributions to many of the emerging but still inchoate branches of natural science of his day. Among the many scientific papers Leibniz published during his lifetime are ones on the nascent science we now know as hydrology. While Leibniz's other scientific work has become of increasing interest to scholars in recent years, his thinking about hydrology has been neglected, despite being relatively broad in extent, including as it does papers on the 'raising of vapours' and the formation of ice, as well as the separation of salt and fresh water. That list can now be extended still further following the discovery of a previously unpublished letter of Leibniz's on the causes of the devastating Lombardy flood of October and November 1705. 
This letter, which will be the focus of our paper, reveals the depth of Leibniz's understanding of key hydrological processes. In it, he considers various mechanisms for the flood, such as heavy rains on high ground, underwater earthquakes, and a mountain collapse. Over the course of the paper we examine each of these mechanisms in depth, and show that Leibniz was in the vanguard of hydrological thinking. We also show that the letter contains one of the first scholarly attempts to apply aspects of the still-forming notion of the hydrological cycle to account for a flood event.

Keywords Leibniz; Lombardy; Flood; Hydrology; Water cycle

\section{Contents}

1. Introduction

2. The text and its background

3. A cause that prevented egress of water from the rivers

4. Mountain collapse

5. Heavy rains

6. Conclusion

Appendix 1. Leibniz to Electress Sophie of Hanover (January 1706).

Appendix 2. Leibniz to Electress Sophie of Hanover (January 1706). English translation.

\section{Introduction}


Although the historical reputation of Gottfried Wilhelm Leibniz (1646-1716) largely rests on his philosophical and mathematical work, it is widely known that he made important contributions to many of the emerging but still inchoate branches of natural science of his day. Among the many scientific papers Leibniz published during his lifetime are ones on the formation of the Earth, ${ }^{1}$ the formation of fossils, ${ }^{2}$ the origin of phosphorus, ${ }^{3}$ and the

1 G. W. Leibniz, 'Protogaea', Acta Eruditorum, (1693), 40-2. English translation in D. R. Oldroyd and J. B. Howes, 'The first published version of Leibniz's Protogaea', Journal of the Society for the Bibliography of Natural History, 9 (1978), 56-60.

2 G. W. Leibniz, 'Epistola ad autorem dissertationis de figuris animalium quae in lapidibus observantur, et Lithozoorum nomine venire possent', Miscellanea Berolinensia, 1 (1710), 118-20; English translation in G. W. Leibniz, Shorter Leibniz Texts, translated and edited by Lloyd Strickland (London, 2006), 142-3. Also Leibniz's letter to Fontenelle published in Histoire de l'Académie Royale des Sciences, (1706), 9-11. Rhoda Rappaport has argued that this letter is in fact Fontenelle's abridgement of, and possibly commentary on, the no longer extant letter that Leibniz sent to Fontenelle, the Histoire's editor. However, the manuscript of Leibniz's handwritten draft of this letter to Fontenelle still exists in the Gottfried Wilhelm Leibniz Bibliothek, Hanover (shelf mark LBr 396 Bl. 128), and corresponds almost perfectly with the version published by Fontenelle, indicating that the Frenchman made no abridgements and few if any editorial changes to Leibniz's letter. See Rhoda Rappaport, 'Leibniz on geology: A newly discovered text', Studia Leibnitiana, 29 (1997), 6-11.

3 G. W. Leibniz, 'Historia inventionis phosphori', Miscellanea Berolinensia, 1 (1710), 91-8; English translation in Acta Germanica: Or the literary Memoirs of Germany, \&c. Done from the Latin and High-Dutch by a society of gentlemen (London, 1742), 73-8. 
separation of salt and fresh water, ${ }^{4}$ which respectively served as contributions to the nascent sciences we now know as geology, palaeontology, mineralogy, and hydrology. While Leibniz's geological and paleontological work has become of increasing interest to scholars in recent years, ${ }^{5}$ his thinking about hydrology has been neglected, ${ }^{6}$ despite being relatively broad in extent, including as it does papers on the "raising of vapours ${ }^{7}$ and the formation of

4 G. W. Leibniz, 'Meditatio de separatione salis \& aqua dultis, novoque separationum chymicarum genere', Acta eruditorum, 1 (1682), 386-8; English translation in Acta Germanica, 157-8.

5 See for example, Catherine Pécaut, 'L'oeuvre géologique de Leibniz', Revue générale des Sciences pures et appliqués, 58 (1951), 282-96; Jacques Roger, 'Leibniz et la théorie de la terre', in Leibniz 1646-1716. Aspects de l'homme et de l'oeuvre. Journées Leibniz, organisées au Centre International de Synthese les 28, 29 et 30 mai 1966 (Paris 1968), 13744; Paolo Rossi, The Dark Abyss of Time: the History of the Earth and the History of Nations from Hooke to Vico (Chicago 1984); Roger Ariew, 'A new science of geology in the seventeenth century?' in Revolution and Continuity: Essays in the History and Philosophy of Early Modern Science, eds. Peter Barker and Roger Ariew (Washington: Catholic University of America Press, 1991), 81-92; E. P. Hamm, 'Knowledge from underground: Leibniz mines the Enlightenment', Earth Sciences History, 16 (1997), 77-99; Claudine Cohen, 'Leibniz's Protogaea: Patronage, mining, and the evidence for a history of the Earth', in Suzanne Marchand and Elizabeth Lunbeck (eds.), Proof and Persuasion: Essays on Authority, Objectivity, and Evidence (Turnhout, 1996), 124-43; Claudine Cohen, 'An unpublished manuscript by Leibniz (1646-1716) on the nature of 'fossil objects", Bulletin de la Société géologique de France, 169 (1998), 137-42; Stuart Elden, 'Leibniz and geography: geologist, 
ice, ${ }^{8}$ as well as the separation of salt and fresh water. That list can now be extended still further following the discovery of a previously unpublished letter of Leibniz's on the causes of the devastating Lombardy flood of October and November 1705. This letter, which will be the focus of our paper, reveals the depth of Leibniz's understanding of key hydrological processes. It was written in January 1706 for his patroness Electress Sophie of Hanover (1630-1714), in response to a request from her niece, the Duchess of Hanover, Benedicte Henriette (1652-1730), who had been informed about the flood and was curious about its cause.

The flood in question remains even today the worst flood disaster in Italian history, claiming a reported 15000 casualties in the Po Valley. ${ }^{9}$ There are two reasons for the terrible toll of life; first, much of the flooding occurred rapidly as the result of dyke failures - most of paleontologist, biologist, historian, political theorist and geopolitician', Geographica Helvetica, 68 (2013), 81-93.

6 The only aspect that has not been ignored is Leibniz's debunking of the divining rod! See Warren Dym, Divining Science: Treasure Hunting and Earth Science in Early Modern Germany (Leiden, 2011), 162ff.

7 G. W. Leibniz, 'De elevatione vaporum, \& de corporibus quae ob cavitatem inclusam in äere natare possunt', Miscellanea Berolinensia, 1 (1710), 123-8; English translation in Acta Germanica, 124-9.

8 G. W. Leibniz, 'De la generation de la glace', Mémoires pour l'histoire des sciences \& des beaux-arts, (September 1701), 201-2. 
the Po and its principal tributaries being already dyked at the time - and, second, the flood unusually occurred in three waves, no doubt catching many unprepared. After mid-October, 1705, heavy rains produced minor flooding around Pavia in the upper valley (see Figure 1). ${ }^{10}$ Then heavy rains and strong scirocco winds on 29-30 October, which melted early snow on the south slopes of the Alps, produced heavy flooding in the provinces of Piemonte and Lombardia between 3 and 6 November. River dykes burst as far downstream as Ferrara and all the principal cities were isolated as islands. Emilia was flooded in turn as flood waters coursed into the distal Po and its distributary channels. Continuing rain produced new flood surges on 9-10 and 12-13 November. On 14 November the flood recession began, but it was the end of the month before normal drainage resumed in the valley.

Needless to say, Leibniz was not privy to such detailed information; he seems to have merely been informed that there had been a devastating flood in the Lombardy region, and then asked for details of its likely cause. That Sophie should turn to Leibniz for an explanation of the flood is not surprising: she often asked him for his thoughts on difficult and curious matters, ${ }^{11}$ and indeed seems to have viewed him as a walking encyclopaedia. The letter itself is important not only because it shows Leibniz to be in the vanguard of

9 P. Salvati, C. Bianchi, M. Rossi, and F. Guzzetti, 'Societal landslide and flood risk in Italy', Natural Hazards and Earth System Sciences 10 (2010), 465-83.

10 The following account is based on descriptions in Guido Alfani, 'Climate, population and famine in Northern Italy: general tendencies and Malthusian crisis, ca. 1450-1800', Annales de Démographie Historique 2 (2010), 41, and in Daniele Salmelli, 'L'alluvione e il freddo: il 1705 e il 1709', in R. Finzi, ed. Le meteore e il frumento: clima, agricoltura e meteorologia a Bologna nel 1700 (Bologna, Il Mulino, 1986), 17-97, especially17-26. 
hydrological thinking, but also because it contains one of the first scholarly attempts to apply aspects of the still-forming notion of the hydrological cycle to account for a flood event.

\section{The text and its background}

In the letter to Sophie, Leibniz considers three possible explanations of the Lombardy flood: (1) heavy rains falling on the higher ground, (2) a 'mountain collapse' damming a river, causing backup and then a catastrophic flood when the dam gave way, (3) a cause which prevented the rivers Po and Adige from discharging into the sea, such as a violent onshore wind, or an underwater earthquake that triggered a tsunami. We shall examine these hypotheses in greater detail shortly. As will become clear, in advancing them Leibniz makes use of recent pioneering theoretical insights regarding the hydrological cycle. In addition to that, his thinking is likely to have been informed by his own firsthand knowledge of the region, and his own geological-geographical research.

Although Leibniz did not witness the Lombardy flood himself, being in Hanover at the time,${ }^{12}$ he had travelled through the affected region some years beforehand, having visited Italy in $1689-90$ while searching for archival materials relating to the history of the noble

11 See for example Sophie's letters to Leibniz concerning the visions and apparent prophecies of Rosamund von der Asseburg, in G. W. Leibniz, Leibniz and the Two Sophies, translated and edited by Lloyd Strickland (Toronto, 2011), 69-74.

12 Leibniz typically wrote his location at the end of his letters, and from this information we know that he was in Hanover at the time. See for example his letter to Electress Sophie of 31 October 1705, in Leibniz and the Two Sophies, 340. 
Guelph house (a history desired by his employer, the Duke of Hanover, for dynastic reasons). Leibniz travelled through the Lombardy region twice, once near the start of his trip as he was making his way south, and then again near the end, when he was making his way northwards. Both times he journeyed over the Po (Figure 1), one of the main rivers which drains the Italian Alps, and on one occasion he also travelled down it by boat. In March/April 1689, he travelled from Venice to Ferrara, and it has been claimed that this would have taken him over the Po Delta. ${ }^{13}$ And this is indeed the case, for according to his biographer, Johann Georg Eckhart, Leibniz travelled by boat from Venice to Mesola, a port-town just south of the Po, from where he travelled to Ferrara by coach. ${ }^{14}$ He stayed in Ferrara a week before departing for the south of Italy. Leibniz was again in Lombardy near the end of his sojourn in Italy: following lengthy stays in Rome, Modena, and Naples, Leibniz returned to Modena at the close of 1689, and on 2 February 1690 departed for Parma. From there he travelled to 13 Erik Amburger, 'Einleitung', in G. W. Leibniz, Sämtliche Schriften und Briefe, erste Reihe, fünfter Band, edited by Deutschen Akademie der Wissenschaften (Berlin, 1954), xxxix. The Sämtliche Schriften und Briefe is the critical edition of Leibniz's writings, in preparation since 1923. There are multiple volumes in eight series. Further references will identify the series number, then volume number, then page number.

14 Eckhart, 'Lebensbeschreibung', Journal zur Kunstgeschichte (1779), 159. Eckhart there records a story that had been oft-told by Leibniz, that during the crossing from Venice to Mesola the boat encountered a bad storm and the Italian crew, fearing for their lives, and believing that their German passenger could not understand them, discussed amongst themselves the possibility of lightening the load by throwing Leibniz overboard and dividing his belongings among themselves. The Lutheran Leibniz, who had overheard the conversation and had picked up enough Italian to understand what was going on, then pulled out a rosary that he had in his pocket and immediately implored God to protect the boat, whereupon the sailors abandoned their plan, believing that to kill a good Catholic, as Leibniz apparently was, would put their souls in jeopardy. 
Brescello, from where he took a boat down the Po to Ferrara, departing Ferrara on 9 February for the Abbey of Vangadizza, which he visited the following day. He subsequently took a boat to Venice, travelling down the Adige. ${ }^{15}$ Leibniz thus travelled down both of Lombardy's major rivers, the Po and Adige, and would have seen at first hand a good part of the area that flooded in 1705. And what he witnessed of the region and its geography stayed with him, for in the letter to Sophie he refers to the use of dykes to hold back the rivers 'as I have seen in the Ferrara region and in the Polesine'.

But Leibniz was no mere tourist passively taking in the landscape from his seat in the post-coach or riverboat. Although his official business in Italy was to examine archival materials for his history of the Guelph family line, he also spent time investigating the geology of some of the areas he visited. The results of these geological researches are to be found in the Protogaea, Leibniz's ambitious work of earth history written between 1691 and 1693 (but published only posthumously, in 1749). ${ }^{16}$ Placing great emphasis on the importance of local knowledge and observations made in situ, the Protogaea contains various insights gleaned from Leibniz's observations in Venice, the Este region (which includes Ferrara in Lombardy), and Modena. ${ }^{17}$ However, much of the Protogaea was informed by even earlier firsthand observations during the extended periods Leibniz spent in the Harz Mountains

15 For details, see Amburger. 'Einleitung', xxxix-xl. For further information about Leibniz's Italian trip, see André Robinet, Iter Italicum (Mars 1689-Mars 1690) (Firenze, 1988).

16 G. W. Leibniz, Protogaea; sive, De prima facie telluris et antiquissimae historiae vestigiis in ipsis naturae monumentis dissertatio, edited by Christian Ludwig Scheidt (Göttingen, 1749). However, Leibniz did publish a summary of the work in 1693: G. W. Leibniz, 'Protogaea', Acta Eruditorum, (1693), 40-2. 
between 1680 and 1686 while serving as a mining engineer. While many of these observations concern the various layers of the earth and the fossil objects found in them, some also concern the origin of springs, changes caused by rivers, and the effects of the sea on the land. A number of the ideas and references in the letter to Sophie are drawn from the Protogaea, and it is not unreasonable to suppose that Leibniz consulted his thirteen year-old manuscript for the Protogaea when composing the letter in 1706. But as we shall see, he also drew on very new ideas about the hydrological cycle (the system of circulation of water at Earth's surface) that were emerging at the time. Let us now consider in greater detail the three explanations for the Lombardy flood he advanced in that letter, taking them in reverse order.

\section{A cause that prevented egress of water from the rivers}

We start with Leibniz's suggestion that there may have been some reason that prevented the rivers Po and Adige from flowing normally, leading water to back up (which we would today call a hydraulic dam) until it burst the rivers' banks and flooded the surrounding area. Leibniz here suggests a variety of mechanisms, such as high tides, high onshore winds, and an underwater earthquake, by which he likely means the tsunami that would be caused by such an earthquake. Leibniz quickly rejects high tides as an option for, while he acknowledges that the gulf of Venice is subject to tides, he also claims (rightly) that these are not sufficiently high as to cause a significant flood. The

17 See G. W. Leibniz, Protogaea, translated and edited by Claudine Cohen and Andre Wakefield (Chicago: Chicago University Press, 2008), 121-9. 
other two suggested mechanisms, namely high onshore winds and an underwater earthquake, were well-known causes of floods in Leibniz's day. Indeed, in the letter to Sophie, Leibniz mentions the report of the Rhône being backed up by high winds in Jacob Spon's Histoire de la Ville et de l'Estat de Geneve. Spon there relates 'an odd occurrence in Geneva on Sunday the 19th of January 1645 between seven and ten o'clock in the morning':

After thunderstorms had raged all night, there arose such a strong wind that in no time at all it drove back the Rhône and the Lake [Geneva] to such an extent that for two hours various people went to the chains on foot and stayed dry, and others crossed from Monnoye to the Island. ${ }^{18}$

In $17^{\text {th }}$ century pamphlets that carried reports of floods, high winds were often cited as the cause; for example, one pamphlet blames a flood in Amsterdam in 1651 on strong northwesterly winds, ${ }^{19}$ while another, reporting on a flood that occurred in London in the same

18 Jacob Spon, Histoire de la Ville et de l'Estat de Geneve, depuis les premiers Siecles de la fondation de la Ville jusqu'à present, 2 vols (Lyon, 1682, 2nd ed): II, 239.

19 [Anon.], Strange and Terrible News, from Holland, and Yarmouth. Being a Perfect Relation, concerning the Inundation of the South Sea; And of its drowning the rich and populous City of Amsterdam; with divers other places in Friesland, Holland, Brabant, and Flanders, and the names of them (London, 1651), 2 . 
year, claims that the River Thames burst its banks on account of a 'great Spring-tide', ${ }^{20}$ occasioned by a strong north-easterly wind which 'forced the waves in abundance from the main Ocean' ${ }^{21}$ In the letter to Sophie, Leibniz mentions similar occurrences in Holland.

As for a tsunami caused by an earthquake, this phenomenon had been known since the $5^{\text {th }}$ century BCE, and was first mentioned by Thucydides in History of the Peloponnesian War:

At around this time $[426 \mathrm{BCE}] \ldots$ the sea at Orobiae in Euboea retreated from what was then the coastline and returned in a tidal wave which hit one part of the town, and as a result of flooding combined with subsidence what was once land is now sea... There was a similar inundation at Atalante, the island off Opuntian Locris, which carried away part of the Athenian fort and smashed one of the two ships laid up there... I believe the cause of this phenomenon to be that the sea retires at the point where the seismic shock is strongest, and is then suddenly flung back with all the greater violence, creating the inundation. I do not think that tidal waves could occur without an earthquake..$^{22}$

20 [Anon.], A True Relation of the Great and Terrible Inundation of Waters, and over flowing of the Lower-Town of Deptford, on Thursday last, about two of the clock in the Afternoon (1651), 3 .

21 [Anon.], A True Relation of the Great and Terrible Inundation of Waters, 4. 
Leonardo da Vinci made mention of the effects of underwater earthquakes in his notebooks. ${ }^{23}$ Closer to Leibniz's day, the aforementioned Histoire de la Ville et de l'Estat de Geneve contains a report that on 16 September 1600 the Rhône was subject to ebbing and flowing, before drying up altogether for several minutes; Spon claimed that the suspension of the waters was likely due to an earthquake which raised the ground between the river and Lake Geneva:

It is very likely that this wonder of nature happened on account of a kind of earthquake, or uprising of the earth, whereby the ground under the place from which the Rhône issues forth from the Lake, being raised three or four times through the agitation of subterranean vapours, prevented this river from flowing, and that when the same ground sank down under its own weight, the river resumed its normal course. ${ }^{24}$

22 Thucydides, History of the Peloponnesian War, III.89. English translation from Thucydides, The Peloponnesian War, trans. Martin Hammond (Oxford: Oxford University Press, 2009), 174.

23 'In eighty-nine [the year 1489] there was an earthquake in the sea of Atalia near Rhodes, which opened the sea, that is its bottom; and into this opening such a torrent of water was poured that for more than three hours the bed of the sea lay bare because of the water that had been lost from it; and then it closed to the former level'. Leonardo da Vinci, Notebooks (Oxford: Oxford University Press, 2008), 287.

24 Jacob Spon (note 18): II, 141. 
An underwater earthquake was also blamed for the destructive waves which hit the Apulia region of Italy in 1627 . According to a contemporary report, a river in the region ceased to flow for two hours following the earthquake, and then 'the sea returned in such a great fury that it drowned two villages, and the river overflowed in other regions, and caused great damage to many houses'. ${ }^{25}$ It was thus common knowledge that high winds and underwater earthquakes impeded the egress of rivers and caused floods, and thus no surprise that Leibniz should consider both mechanisms in his attempt to explain the Lombardy flood. However, neither mechanism could back up the river as far as Pavia (about $250 \mathrm{~km}$ inland, where the river is more than $50 \mathrm{~m}$ above sea level), which was affected by the flood. ${ }^{26}$

\section{Mountain collapse}

25 [Anon.], Recit veritable et espouventable du tremblement de terre arrivé à la Pouille le 30 juillet de la presente année 1627. Traduit d'Italien en François, suyvant la lettre envoyée de Naples (le 7 août 1627) (Lyon, 1627), 11.

26 As it happens, two significant earthquakes were reported in Italy in 1705, both landbased and located in the central Appenines; consequently, an associated tsunami is unlikely. Historic earthquakes in Italy: earthquake.usgs.gov/earthquakes/world/index.phy?region=Italy . Accessed 14022014. 
Leibniz's second suggestion for the Lombardy flood turns on the possibility of a 'mountain collapse' (i.e., a major rock avalanche) blocking the valley of a tributary so that the flow of the stream is impounded, before the impediment itself collapses to create a catastrophic outburst flood. This mechanism is dramatically different from a hydraulic dam in that it entails the release of a large volume of water stored upstream, whereas the latter entails blockage of normal river flow by the increase of water level downstream. In his letter to Sophie, Leibniz mentions that 'not all that long ago' a fallen mountain in the Alps created a lake. Although he does not provide any further detail, the archives of Alpine mountain disasters contain records of various events of this sort, any one of which may have been the one Leibniz had in mind. For example, on 21 February 1602, in the Cirque du Fer à Cheval, Giffre Valley, Haute Savoie (French Alps), a rock avalanche destroyed the village of Entre-deux-Nantes, with 29 casualties, and dammed the Rivière Giffre. When the dam failed under pressure of the stored water the breakout flood destroyed arable land downstream. ${ }^{27}$ In July 1629, a landslide in Alt-Giswil (Obwolden, Switzerland) dammed the Giswilder Laui. On 13 July the dam collapsed and buried the village under 40 metres of debris. ${ }^{28}$

27 Reported in G. H. Eisbacher and J. J. Clague, Destructive Mass Movements in High Mountains: Hazard and Management (Ottawa: Geological Survey of Canada, 1984), paper 84-16.

28 Recorded on www.planat.ch/en/knowledge-base/chronicle/historical-events (Swiss National Platform for Natural Hazards). Accessed 2802 14. Farther back in history, but closer to Lombardy, in 1562 a rockslide off Monte Cremme dammed the river Brenna. On 29-30 May 1565, the dam collapsed and the resulting 'Biasco flood wave' killed 500 
An especially notable case occurred at Plurs (Piura), a village in the Val de Bregoglia on the Swiss-Italian border, which is drained by the River Mera (Maira), a headmost tributary of the Po (via Lago di Como and the River Adda). It had became prosperous by its mining of 'Levazzi stone' (a serpentine rock) from the nearby mountains, from which fire-resistant pottery was made. On 4 September 1618, after intense rains in the period 25 August to 3 September, 3 to 4 million cubic metres of rock and soil collapsed onto the village from Prato del Conto. ${ }^{29}$ The careless excavation techniques of the villagers contributed to the failure, which buried the entire village of 200 buildings with the loss of between 1000 and 2500 lives (almost the entire population). According to a contemporary report from a small pamphlet devoted to the tragedy, the landslide also resulted in a flood:

The aforementioned mountain [the Conto] also blocked the passage of the River Mera, which, not having its vent, and not being able to have it, owing to the impediment of the aforementioned mountain, poured out over the land, and now causes great devastation. ${ }^{30}$

individuals as it swept the Brenna valley as far as Lago Maggiore. Ibid.

29 Reported in Eisbacher and Clague, op. cit.

30 [Anon], Discours deplorable d'un estrange accident survenu le septiesme Septembre, au Bourg de Plurs en la vallee de Valtoline, sujets des Grisons scis sur la riviere de Maira (Lyon, 1618), 7-8. 
Detailed drawings made twenty years later, in 1638, show a sizeable lake where the Mera once ran through the town, along with the new course of the river, south of the new lake. ${ }^{31}$ Leibniz certainly knew of this incident, having mentioned it in the Protogaea. ${ }^{32}$ Such landslides were of course commonplace events in the Alps, and their ability to cause floods was widely known. Indeed, the very same pamphlet which carried details of the Plurs tragedy also noted a number of similar events:

In our time also, a mountain also fell into the Rhône, which made it swell to such an extent that the mills of Geneva turned in completely the opposite direction

31 See the plate by Merian Matthaeus, published in Martin Zeiller, Topographia Helvetiae, Rhaetiae et Valesiae (Frankfurt, 1654), which depicts Plurs before and after the landslide.

32 Leibniz, Protogaea, 117. He also refers to it in a later letter to Louis Bourguet (May 1714), LBr 817 Bl. 66-71. 
from before. ${ }^{33}$ Also, near Tours, a mountain fell into the river, which ruined and inundated all the surrounding land. ${ }^{34}$

That Leibniz should have entertained the possibility that the Lombardy flood was caused by a landslide is therefore not surprising: it was in itself a plausible flood mechanism, as is clear from the numerous examples of it. However, just as strong winds and a tsunami could not have backed up the river $250 \mathrm{~km}$ inland, nor could a landslide wreak havoc over nearly such an extensive area as that affected by the Lombardy flood. And as it happens, while there is a long historical record of landslides in the Alps, no significant event is recorded for $1705 .{ }^{35}$

33 Spon relates a similar incident occurring some years afterwards. He writes that on 21 November 1651, there occurred 'a great overflowing of the Arve, which swept away almost all of the bridges, and made the Rhône rise up on the side of the lake, to the point that the mills of Geneva turned backwards'. Spon, Histoire de la Ville et de l'Estat de Geneve, II: 244.

34 [Anon], Discours deplorable, 8.

35 See Fausto Guzzetti, Colin P. Stark, Paola Salvati, 'Evaluation of Flood and Landslide Risk to the Population of Italy', Environmental Management, 36 (2007), 15-36; P. Salvati et al, op. cit.. 


\section{Heavy rains}

We turn now to Leibniz's principal suggestion for the cause of the Lombardy flood, which is the first one he makes in the letter to Sophie as well as the one to which he devotes most text, namely that the flood may have occurred due to heavy rains falling on high ground. He explains that rain falling on open countryside is concentrated into the narrow confines of stream channels, where its depth and runoff velocity are greatly increased, both factors that threaten the stability of streambanks and built embankments, or overtop them if depth increases too much. Such a suggestion, while obvious today, was certainly not at the time. Indeed, in the $17^{\text {th }}$ century, floods blamed on the rains were generally thought to be caused by the rains falling directly into the rivers. To give a typical example, a pamphlet relating details of devastating floods that occurred throughout Spain in 1617 blamed 'inundations which of late have happened in the Rivers of Ebro, Lobregat, Segre, Cinca, and other Streames issuing and branching from them' ${ }^{36}$ In his letter to Sophie, however, Leibniz notes that the river banks are very narrow, whereas the countryside is of great expanse, and it is the rain that falls there that ultimately causes flooding on lower ground, once the quantity of water exceeds the capacity of the channels to contain it. Thus he writes:

A substantial rain which lasts a long time is sufficient to cause a great flood, and when it makes snow melt, the effect is even greater. The reason which makes the

36 [Anon.], Newes from Spain: A True Relation of the Lamentable Accidents, caused by the Inundation and rising of Ebro, Lobregat, Cinca and Segre, Rivers of Spaine (London, 1618), page numbers not given. This is an English translation of a pamphlet originally written in Spanish by V. Rejaule, the King's Advocate, and published in Valencia, 1617. 
rain sufficient is that it falls on a large area, that is, on wide open countryside, whereas the river channels are very narrow.

In making this suggestion, Leibniz shows the depth of his understanding of hydrological processes, which were only beginning to be properly understood in the latter decades of the $17^{\text {th }}$ century. Indeed, Leibniz's suggestion is possibly the first attempt to apply the fledgling theory of the hydrological cycle to explain a flood event in any physical detail.

To fully appreciate novelty of Leibniz's suggestion, we need to consider developments in hydrological knowledge leading up to the time at which he wrote his letter to Sophie. ${ }^{37}$ The $17^{\text {th }}$ century was marked by an ongoing debate between a majority who still believed the mediaeval concept - inherited from antiquity - that rivers originated from some subterranean plumbing system that connected the ocean with the mountains, and a few who believed in the adequacy of rainfall to feed the rivers. The former generally had the upper hand inasmuch as they drew authority from the Bible. ${ }^{38}$ Against this, rainfall advocates had at this time no definitive evidence, which would have to be in the form of measurements of precipitation and streamflow. ${ }^{39}$ The general form of the subterranean plumbers' argument involved variations on a theme of deep subsurface

37 The history of hydrology is not well researched. The most comprehensive text is Asit K. Biswas, History of hydrology (Amsterdam: North Holland Publishing Company, 1970). The discussion immediately below is informed by this book.

38 'All rivers run to the sea; yet the sea is not fully unto the place whence the rivers come, thither they return again'. Ecclesiastes 1.7 (King James translation). 
conduits leading from the seas to caverns in the mountains where water was raised to the highest topography either by evaporation in the warm, deep earth and subsequent condensation in the cold, upper earth or, alternatively, by somehow being pumped to the highest elevations by tidal forces in the sea or by wind and waves. Once it was realised that filtration (through the earth) would not remove dissolved salt from water, the evaporation theory had the advantage of incorporating an explanation of how water became fresh. Influential exponents of this view included Georgius Agricola (1494-

39 Elements of both theories can be traced back to classical Greece. Aristotle, whose writings remained authoritative until the time of the European Renaissance, elaborated aspects of both. Similarly, Leonardo da Vinci (1452-1519) expounded both theories (on the same manuscript sheet!), though his writings remained unpublished. Precipitation measurements began to become common in the $18^{\text {th }}$ century, but it was the mid- $19^{\text {th }}$ century before streamflow measurement became a routine activity. 
1555), ${ }^{40}$ René Descartes (1571-1650) ${ }^{41}$ Athenasius Kircher (1602-1680), ${ }^{42}$ Johann Joachim Becher (1635-1682), ${ }^{43}$ and Bernhardus Varenius (1622-1650), whose Geographia generalis (1650) remained the standard geography textbook for almost a century. ${ }^{44}$

Against the opinion of these major scholars, the earliest cogent account of something like the modern concept of the hydrological cycle was contributed by Bernard 40 Georgius Agricola, De re metallica (Basil, 1556). English translation: De re metallica, trans. Herbert Clark Hoover and Lou Henry Hoover (New York: Dover, 1950). This book remained influential for more than a century, and Leibniz knew it well, citing it in various writings.

41 René Descartes, Discours de la méthode, incorporating an essay Les météores (1637), which contains some elements of a modern approach to evaporation and precipitation. However, he did not connect these phenomena with runoff, expounding instead the subterranean theory.

42 Athenasius Kircher, Mundus subterraneus (Amsterdam, 1664). This was the standard textbook of geology of the $17^{\text {th }}$ century. A fellow Jesuit, Gaspard Schott (1608-1666) allowed that rainfall might feed small streams.

43 Johann Joachim Becher, Chymisches laboratorium (Frankfurt, 1680).

44 Bernhardus Varenius, Geographia generalis (Amsterdam, 1650). 
Palissy (1510?-1590). Palissy clearly guessed the true nature of the hydrological cycle and published his views in Discours admirable $(1580) \cdot{ }^{45} \mathrm{He}$ asserted unequivocally that rainfall gave rise to rivers. Further, he understood and described the initial seepage of rainwater into soil and rock and its re-emergence at springs to form the initial streams. He went on to describe the joining of streams to form larger rivers. Amongst the key evidence he cited for his views was the occurrence of low water or complete drying up of water courses during rain-free summers. Palissy also correctly explained the origin of artesian wells. But he was not a recognised scholar; he wrote in Middle French rather than Latin, and so his views were not immediately influential or even widely noted. ${ }^{46}$

45 Bernard Palissy, Discours admirables, de la nature des eaux et fontaines, tant naturelles qu'artificielles, des metaux, des sels \& salines, des pierres, des terres, du feu et des emaux (Paris, 1580). English translation: The Admirable Discourses of Bernard Palissy, trans. Auréle La Rocque (Urbana: University of Illinois Press, 1957).

46 There are other indications that ordinary folk of the fields and hills shared elements of this more sophisticated knowledge. We find in pamphlets of the day testaments such as the following, which clearly demonstrates appreciation of a rainfall-runoff relation: 'The sixt and last reason why the fens are often drowned, is because there is no Land Eayes to receive the surplussage of the waters which proceed from Raine and Snow falling upon the high Lands adjacent to the Fens, and to carry them into those Rivers or Draines which are next unto them.' A Briefe Relation discovering plainely the true Causes why the great Levell of Fenns in the severall Counties of Norfolk, Suffolk, Cambridge, Huntington, Northampton, and Lincoln Shires; being three hundred and seven thousand acres of Low-Lands, have been drowned, and made unfruitfull for many yeares past (London, 1642), 6. 
So in spite of the observations of Palissy, and assertions of some other scholars, among them Isaac Voss (1618-1689), ${ }^{47}$ Honoré Fabri $(1607-1688)^{48}$, and Robert Hooke (1635-1703), the dominant view near the end of the $17^{\text {th }}$ century remained the one epitomised in this remark of Gilbert Burnet (a future Bishop of Salisbury) from 1686:

These springs [in Switzerland] doe very probably flow from some vast cavities that are in the neighbouring Mountains, which are as great Cisterns that discharge themselves in the Valleys which are covered over with Lakes. ${ }^{49}$

Definitive evidence for a surface-based hydrological cycle was apparently first brought forward by Pierre Perrault (1608-1680) ${ }^{50}$ a disgraced French civil servant. He estimated the rainfall-runoff balance of the uppermost Seine River, showing that annual rainfall was more than adequate to supply the runoff: in fact, runoff was estimated to account for only $20 \%$ of rainfall. ${ }^{51}$ A more influential assertion of the rainfall theory was published in 1686 by Edmé Mariotte (c.1620-1684), a leading physicist of the day, in his 47 Isaac Voss, Variarum observationum liber (London, 1685).

48 Honoré Fabri, Physica (Lyon, 1670), vol. 3.

49 Gilbert Burnet, Some Letters, Containing an Account of what Seemed Most Remarkable in Switzerland, Italy \& etc. (Rotterdam, 1686), 14.

50 De l'origine des fontaines: originally a privately circulated document, published anonymously in 1674, translation by A. LaRocque, Origin of fountains (New York: Hafner, 1967). 
posthumous Traité du mouvement des eaux et des autres corps fluides. ${ }^{52}$ Mariotte expanded Perrault's analysis (Mariotte's work is probably modelled on Perrault's, but that remains uncertain) by treating the entire Seine basin as far down as Paris based on his own measurements of river velocity (using floats) and a considerable precipitation record from Dijon. He concluded that the Seine discharges less than $16 \%$ of incoming rainfall. Further, the spring at Montmartre he estimated to return only $25 \%$ of local precipitation. Mariotte directly debunked the cavern theory. John Ray (1627-1705) subsequently sketched the main features of the hydrological cycle very shortly after the appearance of this first quantitative work..$^{53}$

The final piece of the puzzle of the hydrological cycle - the efficacy of evaporation to provide precipitable water to the atmosphere - was filled in by Edmond Halley (1656-1742). In a series of papers published between 1687 and 1715 in the Philosophical Transactions of the Royal Society he used limited measurements of pan evaporation and a huge extrapolation to the Mediterranean basin to establish that evaporation could supply far more than enough precipitable water to account for

51 Perrault relied on rather crude precipitation measurements and made first order estimates for the runoff by estimating channel dimensions and flow velocity.

52 Edmé Mariotte, Traité du mouvement des eaux et des autres corps fluides (Paris, 1686).

53 The wisdom of God manifested in the works of creation (London, 1691). 
precipitation onto the land surface. Key papers were published in 1687 and $1694 .{ }^{54}$ By 1700 , one may say that the modern principle of the hydrological cycle was established, though opposition continued through the $18^{\text {th }}$ century and even into the $19^{\text {th }}$.

Leibniz was acquainted with the work of Palissy, Mariotte and Halley, and through them probably that of Perrault as well, though we have no direct evidence for

54 Edmund Halley, 'An estimate of the quantity of vapour raised out of the sea by the warmth of the sun', Philosophical Transactions 16 (1687), 366-70; 'An account of the evaporation of water', Philosophical Transactions 18 (1694), 183-90.

55 It is interesting that all three of these investigators made (and got away with) essentially indefensible assumptions. In the case of Perrault and Mariotte, it was that rainfall at a point adequately indexes water input to a more or less extended region. Furthermore, their streamflow estimates were undoubtedly very poor. In Halley's case, the extension of very limited point measurements to a large part of Earth's surface is inadmissible. They got away with these assumptions because, in both cases, they were comparing one quantity (respectively, runoff or precipitation onto the land) with another, very much larger quantity (respectively rainfall and evaporation from the sea). In the first case, runoff is a small residual difference between rainfall and evaporation; in the second, rainfall onto the land comprises a small part of global evaporation, most of which reprecipitates onto the world ocean. So the undoubted gross biases in their 'measurements' disappeared into the magnitude of the unassessed additional term. 
that. ${ }^{56}$ He knew Mariotte personally: the two met during Leibniz's time in Paris (16721676), and thereafter they corresponded until Mariotte's death in $1684 .{ }^{57}$ After much searching ${ }^{58}$ Leibniz finally succeeded in getting hold of a copy of Mariotte's Traité $d u$ movement des eaux in $1701,{ }^{59}$ though very probably he knew of some of its contents earlier than that from Mariotte himself. ${ }^{60}$ As for Halley, Leibniz was an avid reader of the

56 Leibniz was certainly aware of Perrault's book (see Sämtliche Schriften und Briefe, III $2,407)$, though there is no evidence that he ever read it.

57 Their correspondence largely concerned topics in physics (colours, mechanics etc.).

58 He writes to Bernoulli in 1698: 'That little book [Traité du movement des eaux] was never published, because the author was prevented by death; yet I do not doubt that it is circulating in the hands of some. If it could be obtained, I would gladly pay the price'. Leibniz to Johann Bernoulli (7/17 June 1698), in Sämtliche Schriften und Briefe, III 7, 795. This means Leibniz had not read Traité du movement des eaux at the time of writing the Protogaea.

59 See Leibniz's unpublished notes from 1701 on Mariotte's Traité du movement des eaux, in the manuscript held in the Gottfried Wilhelm Leibniz Bibliothek, Hanover, shelf mark LBr 413, Bl. 69. Leibniz's notes relate to the section of Mariotte's book concerning the origin of winds (pp34-73 of the 1686 edition of the Traité). Among the topics that caught Leibniz's attention was Mariotte's explanation of the role of the winds in the November rains in central and southern France.

60 Leibniz later recounted to one correspondent how he had witnessed experiments in the presence of Mariotte, and near the end of life — and almost thirty years after Mariotte's 
Philosophical Transactions, and very likely had read Halley's papers on evaporation. ${ }^{61}$ Moreover, he and Halley briefly corresponded in 1692, and then again from 1703 to 1705 following their meeting in Hanover in the summer of $1703 .{ }^{62}$ Finally, Leibniz was certainly aware of Palissy's work, expressing a desire that it be translated (presumably into Latin, from the original Middle French) ${ }^{63}$ The influence of the work of these thinkers

passing — he described Mariotte as a friend. For the former, see Leibniz to Simon Foucher (23 May 1687), in Sämtliche Schriften und Briefe, II 2, 203, and for the latter, see Leibniz to Varignon (28 June 1713), in Leibnizens mathematische Schriften, edited by C. I. Gerhardt (Halle: H. W. Schmidt, 1859), IV: 193.

61 There are references in Leibniz's writings to some of the papers Halley published in that journal; for example, he mentions 'An account of the cause of the change of the variation of the magnetical needle, with an hypothesis of the structure of the internal parts of the earth', Philosophical Transactions (19/29 October 1692), 563-78. See Leibniz's letter to Huygens (4/14 September 1694), Sämtliche Schriften und Briefe, III 6, 184.

62 See Sämtliche Schriften und Briefe I 22, 756.

63 In his diary (Tagebuch) entry for 26 September/6 October 1697 Leibniz wrote 'There should also be some translation done of Palissy's book'. G. W. Leibniz, Gesammelte Werke aus den Handschriften der Königlichen Bibliothek zu Hannover. Erste Folge, Vierter Band, edited by Georg Heinrich Pertz (Hanover, 1847), 218. Unfortuately it is not clear which of Palissy's books Leibniz had in mind; his access to a number of the royal libraries of Germany means that he had access to all of Palissy's works. 
is evident in Leibniz's Protogaea. While it mostly concerns matters related to mining and the solid Earth, there are references to the hydrological cycle other than the question of the origin of springs:

I know there are those who, by reason of springs that originate on the highest mountains, hope to reject rain as the source of rivers, as though some motor other than the natural weight of the flowing water ... had to be at work in springs. But the little stream on Bructerus ${ }^{64}$ does not originate on the peak itself. Rather, it only unloads the spillover from the damp earth, which itself comes from an even higher place. I hardly doubt that the same thing also happens in other places. ${ }^{65}$

It is clear that Leibniz believes in rainfall as the origin of runoff on Earth's surface: 'Indeed, it is well established that rainwater or snow form [sic $]$ springs. ${ }^{96}$ This belief lies behind his suggestion in the letter to Sophie that heavy rains falling on high ground may

\section{Mount Belibocus, near Darmstadt.}

65 Leibniz, Protogaea, 19-21. It is worth noting that Leibniz also had his own first-hand experience to draw on. Much of his work in the Harz mines involved designing and overseeing wind-driven pumps to pump out the water which constantly seeped into the mines, hampering the extraction of silver. At the very least, we may surmise that his experience trying to raise water out of mines is likely to have made him particularly suspicious of the 'subterranean plumbers' and their idea of raising water to the mountain tops, if not actually affording him positive data and insights about the natural movement of water.

66 Leibniz, Protogaea, 57. 
have been the cause of the Lombardy flood. In framing this hypothesis, Leibniz shows that he understood the implications of the data of Perrault and Mariotte, so that he had, for the time, an advanced view of hydrological processes. Although Leibniz does not reveal the source of his opinion, it is likely to be Mariotte. In the Sophie letter he also shows that he is aware of contemporary efforts to measure rainfall, and the significance of this:

Observations have been made on the quantity of water that falls from the sky, and it has been noticed, for example, that all the rains of the month of September in 1699 caught in a barrel in Paris went up to 3 inches or thereabouts. A single heavy rain can produce as much and more than the whole of a month, and all this water, which would cover the high country up to half a foot if it remained there, when coming down suddenly into the low and cramped-in places or several concurrent rivers, is capable of covering the countryside and of producing a kind of lake.

The fact that Leibniz advances three hypotheses for the Lombardy flood indicates that he himself did not know the true cause. He ends the letter by noting the data that would be required to enable a determination of the true cause of the flood. The data Leibniz required are now readily available, and consequently we know that, of Leibniz's three hypotheses, that of heavy rains falling on higher ground most accurately reflects the true cause.

\section{Conclusion}


Leibniz does not feature in histories of hydrology, ${ }^{67}$ and certainly it would be difficult to claim that he had any direct role in shaping our understanding of the hydrological cycle, or its application. Nevertheless, the Sophie letter shows that Leibniz was at the forefront of hydrological thinking (as he was with just about every other science of his day), and was able to apply the latest theoretical insights to understand real-life flood events. It is notable that of the three hypotheses advanced, the heavy rains hypothesis was the first one mentioned (suggesting that it was perhaps his first thought), and also that he devotes more space to that than he does to the alternative hypotheses also considered. While the rainfall-runoff concept as the origin of floods is second nature to us today, based on our understanding of the hydrological cycle, these were intellectually revolutionary ideas in Leibniz's time.

While it is tempting to suppose that Leibniz passed on his insights only to the recipient of the letter, Electress Sophie, this should be resisted. After all, much of the transmission of knowledge in Leibniz's day was accomplished verbally or via letters exchanged within a small international community of European savants. Given that circumstance, and Leibniz's wide circle of scholarly acquaintances, many of whom he met in the flesh, it is very likely that his cutting-edge views were transmitted beyond the circle of his royal patrons and influenced the increasing recognition, after 1700, of the modern concept of the hydrological cycle. Future discoveries in the Hanover archives may further flesh out this picture.

67 Biswas, op. cit. 


\section{Acknowledgements}

The authors would like to thank two anonymous referees, as well as Stuart Elden, and Daniel J. Cook for their comments on an earlier draft of this paper; Eric Leinberger for construction of Figure 1; Matteo Salmetti for translating passages from the monograph of Daniele Salmelli; Nora Gaedeke and Charlotte Wahl for transcribing Leibniz's reading notes on Mariotte; and Sabine Sellschopp and Julia Weckend for assisting with the translation from old German of Leibniz's remarks on Palissy.

\section{Appendix 1. Leibniz to Electress Sophie of Hanover (January 1706) ${ }^{68}$}

Hanover janvier 1706

Pour satisfaire à la curiosité de Madame la duchesse d'Hanover sur la cause de la grande inondation qui a ravagé la Lombardie dernierement, il faudrait estre informé de plusieurs circonstances qui nous sont inconnues.

L'inondation a esté causée ou par l'abondance des eaux qui venoient des endroits plus hauts, et ne pouvoient pas estre contenues dans les lits des rivieres; ou par une cause

68 Transcribed from the manuscript held by the Gottfried Wilhelm Leibniz Bibliothek, Hanover, shelf mark LH VI, 1, Bl. 1-2. 
qui empechroit les rivieres de se decharger, ou peutestre par $^{69}$ les deux causes jointes ensemble. ${ }^{70}$

Une pluye copieuse qui dure long-temps suffit pour causer une grande inondation, et quand elle fait fondre des neiges, l'effect en est encor plus grand. La raison qui fait suffire la pluye est qu'elle tombe sur un grand espace, c'est à dire sur une ${ }^{71}$ grande campagne ouverte au lieu que les lits des rivieres sont fort serrés. j'ay experimenté un jour d'esté à deux lieues d'Hanover que la pluye d'une seule nuit avoit tellement fait inonder un endroit ${ }^{72}$ ou le grand chemin passe et ou il n'y a qu'un petit ruisseau, que le pont ne paroissent plus, et sans les paysans qui m'en avertirent a grand matin, j'aurois pû perir là avec chevaux et carosse.

On a fait des observations sur la quantité d'eau qui tombe du ciel, et on a remarqué par exemple que toutes les pluyes du mois de septembre ${ }^{73}$ en 1699 receues dans un tonneau sont allées à paris à la hauteur de 3 poices ou environ. Une seule pluye forte peut faire autant et plus que tout en un mois, et toute cette eau qui couvriroit le pays hauts

69 par I l'une et l'autre I deleted.

70 ๆ Des grandes pluyes suffisent

71 une I campagne entiere, et les lits des rivieres I deleted.

72 endroit I ou l'on passé ordinairement I deleted.

73 septembre I sont allees quelques fois à la hauteur I deleted . 
à la hauteur d'un demypied si elle y restoit, descendant tout d'un coup dans les lieux bas et serrés ou plusieurs rivieres concourent, est capable d'y couvrir la campagne et d'y faire une espece de lac.

Ce qui a lieu d'autant plus quand la campagne y a des grandes plaines basses, d'ou l'eau n'écoule que par l'artifice des hommes, qui ont fait des canaux, et qui tiennent les rivieres comme suspendues par le moyen des digues comme je l'ay vu dans le Ferrarois et dans le polesine.

L'on pretend aussi que presque toute la coste depuis venise jusqu'à Ravenne estoit couverte d'eau autresfois, jusqu'à ce que l'art y a remédié. Il y avoit un lac, nommé padusa, encore du temps des Romains. Et l'on dit qu'un certain Emilius Scaurus Romain a fait des grands travaux pour dessecher une partie des marais de ce pays là.

Il est vray cependant que les inondations peuvent encor venir, lors que l'issue des eaux des rivieres est bouchée ou rendue plus lente et plus difficile. Et il n'y a pas long temps qu'une montagne tombée dans les Alpes ayant bouché le cours d'une riviere y a causé un lac.

L'issue des eaux des rivieres peut estre rendue difficile aussi par des marées extraordinairement hautes. Le Golfe de venise a des marées, mais je ne croy pas qu'elles soyent jamais assez hautes pour causer une inondation notable.

Lors qu'un vent violent est combiné avec le flux, et que d'ailleurs le flux de la marée est d'une hauteur extraordinaire, comme l'on pretend qu'il arrive le plus dans les temps des equinoxes et des syzygies de la lune et du soleil; on experimente sur tout en Hollande, qu'il en naissent des grandes inondations. Les vents sont quelque fois assez violens pour empecher le Cours d'une riviere dans un endroit estroit. l'histoire de 
Geneve remarque qu'un jour la Rhone fut tellement suspendu par cette force, que ce qui estoit plus bas demeura à sec. M Worstley aura compte sa conte à Madame l'Electrice de Bronsvic qu'il n'y a pas long temps que le vent a soutenu le jordan, et qu'on y a passé à sec. La mer peut encor estre gonflée par un tremblant de terre sous marin, que les italiens appellent terremoto di mare comme je le voy dans le lettre de Madame la Duchesse. Et l'italie estant sujette aux tremblemens de terre, ce ne seroit pas une chose fort extraordinaire que la mer s'en ressentit.

La premiere fois que j'entendis parler des ourragans c'est à dire des vents extraordinaires qui font des terribles ravages principalement dans l'Amerique méridionale, je soupçonnay ${ }^{74}$ que ce vent fort de la terre et y cause quelques fois un tremblement sousmarin, ce que des relations des voyageurs confirment.

Mais pour appliquer ces causes à nostre fait, il faut ${ }^{75} \mathrm{~s}^{\prime}$ informer (1) s'il y a eu des grandes pluyes dans les pays hauts immediatement avant l'inondation (2) s'il y a eu en ce temps la un tremblement de terre sensible. Car s'il y en avoit un sousmarin dans le Golfe, il ne semble pas que la coste en ait pû estre tout a fait exemte (3) s'il y a eu un vent violent contraire à l'issue du po et de l'Athese. Et (4) si l'inondation a commencé par le

74 soupçonnay I qu'il y avoit un tremblement de terre sousmarin joint au vent terrible $(\alpha)$ et que meme ce vent surtout $(\beta)$ de la terre et cela a esté confirmé par les relations des voyageurs. Mais il n'est I deleted.

75 faut I examiner si les inondations ont commence plus bas ou plus haut I deleted. 
bas ou par le haut pour mieux determiner ${ }^{76}$ si l'abondance des eaux survenues ou l'empechement de l'issue a eu plus de part à l'inondation.

\section{Appendix 2. Leibniz to Electress Sophie of Hanover (January 1706). English translation.}

Hanover, January 1706

In order to satisfy the curiosity of Madam the Duchess of Hanover ${ }^{77}$ about the cause of the great flood that devastated Lombardy recently, we would have to be informed about several circumstances that are unknown to us.

The flood was caused either by the abundance of the waters which came from higher places, and could not be contained in the river banks, or by a cause that prevented the rivers from flowing, or perhaps by ${ }^{78}$ the two causes combined. ${ }^{79}$

76 determiner I si il en faut attributer la cause de l'abondance I deleted.

77 Benedicte Henriette, Duchess of Hanover (1652-1730).

78 by I both I deleted.

79 combined. I ๆ Substantial rains are sufficient I deleted. 
A substantial rain which lasts a long time is sufficient to cause a great flood, and when it makes snow melt, the effect is even greater. The reason which makes the rain sufficient is that it falls on a large area, that is, on ${ }^{80}$ wide open countryside, whereas the river channels are very narrow. One day I had the experience, being two leagues from Hanover, that a single night's rain had so flooded a place where the main road passes, and where there is only a small stream, that the bridge was no longer visible, and without the country folk who warned me early in the morning I could have died there with horses and coaches.

Observations have been made on the quantity of water that falls from the sky, and it has been noticed, for example, that all the rains of the month of September ${ }^{81}$ in 1699 caught in a barrel in Paris went up to 3 inches or thereabouts. ${ }^{82}$ A single heavy rain can produce as much and more than the whole of a month, and all this water, which would cover the high country up to half a foot if it remained there, when coming down suddenly into the low and cramped-in places or several concurrent rivers, is capable of covering the countryside and of producing a kind of lake.

80 on I the whole countryside and the river channels I deleted.

81 September I sometimes went up to I deleted.

82 Leibniz is referring here to de la Hire's 'Observation du barometre, du thermométre, \& de la quantité d'eau de pluie \& de neige fondue qui est tombée à Paris dans l'Observatoire Royal pendant l'année 1699', Histoire de l'Academie Royale des Sciences (1700), 6-9, especially 6-7. 
This holds good all the more when the countryside there has great low plains, from which the water only flows out by means of the artifice of men, who build canals, and who keep the rivers suspended, as it were, by means of dykes, as I have seen in the Ferrara region and in the Polesine. ${ }^{83}$

It is also claimed that almost the whole shore from Venice to Ravenna was once covered with water, until artifice remedied it. ${ }^{84}$ There was a lake, called Padus, even at the time of the Romans. ${ }^{85}$ And it is said that a certain Roman, Aemilius Scaurus, made great efforts to dry out some of that country's marshes. ${ }^{86}$

83 For further details see Leibniz, Protogaea, 121.

84 For further details see Leibniz, Protogaea, 123.

85 See Cassiodorus, Variae 12.24.

86 Marcus Aemilius Scaurus (c. 168-88BCE), Roman statesman. Leibniz is thinking of the following passage from Strabo's Geography V.1.11. 'there is also a voyage thence by the Padus down to Ravenna which takes two days and nights. Now a considerable part of Cispadana too used to be covered by marshes (through which Hannibal, on his advance against Tyrrhenia, passed only with difficulty); but Scaurus drained the plains by running navigable canals from the Padus as far as Parma; for near Placentia the Padus is joined by the Trebia, as also before that by several other rivers, and is thus made excessively full. This Scaurus is the man who constructed the Aemilian Way which runs through Pisa and Luna as far as Sabata and thence through Derton'. 
It is nevertheless true that floods can still occur when the way out for the waters of the rivers is blocked or made slower and more difficult. And it was not all that long ago that a fallen mountain in the Alps, having blocked the course of a river there, caused a lake. ${ }^{87}$

The egress of the waters from rivers can also be made difficult by extraordinarily high tides. The gulf of Venice has tides, but I do not think that they are ever high enough to cause a notable flood.

When a violent wind is combined with the incoming tide, and when, moreover, the flow of the tide is of an extraordinary height, as is claimed happens most at the times of the equinoxes and syzygies of the moon and sun, the experience is, especially in Holland, that it gives rise to great floods. The winds are sometimes violent enough to hinder the course of a river in a narrow place. The History of Geneva recounts that one day the Rhône was so suspended by this force that the lower part remained dried up. ${ }^{88} \mathrm{Mr}$ 87 Leibniz may here have in mind one or other of the events recounted in the Protogaea: 'I will not speak of mountain collapses, like what happened in the canton of Bern, in the Alps of Villach, and in the Rhaetian Alps, where, as our fathers remember, the town of Plüos was smothered, and also in the territory of Firmano, where the so-called Mountain of the Caverns collapsed in 1670'. Leibniz, Protogaea, 117.

88 Leibniz made the same reference in the Protogaea: 'The history of Geneva recounts how winds stopped the flow of the Rhône River, piling its waters into a heap and making it possible to walk across the dry riverbed'. Protogaea, 57. The reference is to what Jacob Spon, the author of the history of Geneva, called 'an odd thing which occurred in Geneva on Sunday the 19th of January 1645 between seven and ten o' clock in the morning'. 
Worsley will have told his tale to Madam the Electress of Brunswick that it was not long ago that the wind supported the Jordan, and that one crossed over it dried up. ${ }^{89}$ The sea can even be swollen by an underwater earthquake, which the Italians call terremoto di mare [earthquake of the sea] as I saw in the letter from Madam the Duchess. And as Italy is prone to earthquakes, it would not be a very extraordinary thing for the sea to feel the effects of them.

The first time I heard talk about hurricanes, that is, freakish winds which wreak havoc principally in Southern America, I suspected ${ }^{90}$ that this strong wind over the land also sometimes causes an underwater quake, which is confirmed by travellers' accounts.

Spon explains: 'After thunderstorms had raged all night, there arose such a strong wind that in no time at all it drove back the Rhône and the Lake [Geneva] to such an extent that for two hours various people went to the chains on foot and stayed dry, and others crossed from Monnoye to the Island'. Jacob Spon (note 18) : II, 239.

89 Leibniz refers to a Mr Worsley in the New Essays (1703-05), describing him as an 'observant traveller'; see Sämtliche Schriften und Briefe, VI 6, 248. The editors from the Berlin Academy have been unable to identify him, however, and conjecture that he may be the Mr Wichley briefly discussed by Leibniz and Electress Sophie, in an exchange of letters in 1703. See Sämtliche Schriften und Briefe, I 22, 97 and 102.

90 suspected I that there was an underwater earthquake together with a terrible wind $(\alpha)$ and that this wind especially $(\beta)$ over the land, and this has been confirmed by travellers' accounts. I deleted. 
But to apply these causes to our matter, we should ${ }^{91}$ find out (1) If there has been heavy rains in the high countries immediately before the flood. (2) If there has been in this time a perceptible earthquake. For if there was an underwater one in the gulf, it does not seem that the coast was able to be completely exempt from it. (3) If there has been a violent wind contrary to the egress from the Po and Adige. And (4) if the flood started with the low or the high, to better determine ${ }^{92}$ whether the abundance of unexpected waters, or whether an obstacle to its egress, has had more of a role in the flood.

\section{Caption for figure 1}

Northern Italy, showing the conjectured extent of the 1705 flooding in the Po Valley (based on a partial map in Salmelli and on written descriptions), and Leibniz's route in the region in 1689-90. Political boundaries are modern, to aid reader orientation.

91 should I investigate whether the inundations begun lower or higher I deleted.

92 determine I if the cause of the abundance should be attributed to I deleted. 